DOI: https://doi.org/10.47405/mjssh.v6i10.1081

\begin{tabular}{|c|c|}
\hline 4 & Malaysian Journal of Social Sciences and Humanities (MJSSH) \\
\hline $\begin{array}{l}\text { Malaysian Juoural of } \\
\text { Social ccciecces and }\end{array}$ & Volume 6, Issue 10, October 2021 \\
\hline (MJ-sSH) & e-ISSN : 2504-8562 \\
\hline & $\begin{array}{l}\text { Journal home page: } \\
\text { www.msocialsciences.com }\end{array}$ \\
\hline
\end{tabular}

\title{
The Feasibility of Mandatory Vaccination Program Under the Malaysian Legal Framework for Education Sector
}

\author{
Hariz Sufi Zahari' ${ }^{1}$, Zuhaira Nadiah Zulkipli' ${ }^{1}$, Sharifah Nur Asmaa' Syed Azman', \\ Ahmad Ridhwan Abd Rani ${ }^{1}$ \\ 1Faculty of Law, University Teknologi MARA, Malaysia
}

Correspondence: Hariz Sufi Zahari (harizsufi@uitm.edu.my)

\begin{abstract}
The spread of the COVID-19 virus has been halted partially due to the vaccination program around the globe. However, such initiation has been actively under attack by a portion of society that believes vaccination is not the way out of the pandemic. A similar notion of anti-vaccine has slipped through Malaysia, particularly in the education sector, as they refuse to be vaccinated. This has been contributed by the lack of legal provision that regulates vaccination in Malaysia. Based on the literature and scientific data on the effectiveness of vaccination programs in curbing the spread of COVID-19, this paper aimed to weigh the legal argument on the possibility of imposing mandatory COVID-19 vaccination in Malaysia's education sector to eradicate this deadly disease virus permanently. This paper embarked on a comparative, doctrinal analysis methodology where secondary data were collected and analysed. Literature from primary and secondary sources such as the laws, guidelines, textbooks, journal articles, government reports, newspaper articles, and online sources from multiple jurisdictions was analysed. The outcome of such analysis is laid down in a narrative design in highlighting the importance of mandatory vaccination within the education sector. This paper proposed hard and soft approaches on imposing mandatory vaccination programs within the education sectors in Malaysia is highly recommended, considering that the benefits of vaccination outweigh the risk of eradicating COVID-19 in Malaysia.
\end{abstract}

Keywords: COVID-19, mandatory, vaccination, legal framework, education sector

\section{Introduction}

The 2019 coronavirus outbreak in Wuhan, China, began in the Hunan seafood market, where bats, snakes, raccoons, dogs, palm civets, and other animals were traded and quickly expanded to 109 countries (Xu, Chen, Wang, 2020). The zoonotic source of SARS-CoV-2 is unknown; however, sequence-based research has implicated bats as the predominant source (Ji, Wang, Zhao et al., 2020). Until now, no effective therapeutic or preventive strategies against human coronaviruses have been discovered. However, there are encouraging initiatives to restrict the virus, as seen by the recent COVID-19 vaccinations and government immunisation policies and practices. Vaccination is the process of administering a vaccine to the body in order to protect against a certain disease. A vaccine itself is a substance that is used to boost the body's immunological response against illnesses. Vaccines are often given through needle injections; however, some can also be given orally or through the nose. (CDC, 2021). 
Within the global literature, the notion of mandatory vaccination has been debated long before the spread of COVID-19. To this day, it is estimated that around 54\% of the countries around the globe have mandated compulsory vaccination within their legal framework. From the total of 105 countries that mandated compulsory vaccination programs, only 59\% of the said countries had at least one penalty for non-compliance (Gravagna et al., 2021). Turkmenistan became the first country to make vaccination mandatory for all adults (Dyer. O, 2021). The literature from Greece indicates that almost $87 \%$ of the population supported mandatory vaccination programs for its citizens (Giannouchos et al., 2021). Similar trends can be observed from the literature from France that is inclined towards mandatory vaccination for the education sector (Verger et al., 2021).

In Malaysia, the vaccination program was initiated back in February 2021. As of February 2021, Malaysia has access to a supply of COVID-19 vaccine of 66.7 million doses through the COVAX Facility and initial purchase of 5 manufacturers of COVID-19 vaccine. Of the five vaccine manufacturers, the vaccine from Pfizer-BioNTech has obtained conditional approval from the Authority Drug Control (PBKD) and NPRA on 8 January 2021. At the same time, four vaccine candidates for COVID-19 were being processed for NPRA approval (National COVID-19 Immunisation Programme, 2021). In August 2021, Malaysia topped the world's highest vaccination rates list (Radhi, 2021). Unfortunately, the anti-vaccine movement has emerged rapidly among Malaysians. The movement has garnered a substantial number of people from various disciplines, including the education sector. As a response, numerous civil society organisations have called for the enforcement of the Prevention and Control of Infectious Disease Act and to introduce a mandatory vaccination clause within the said law.

This paper examines the feasibility of mandatory vaccination programs under the Malaysian legal framework for the education sector. This paper intends to fill in the literature gap on the Malaysian perspective of mandating vaccination programs to combat the spread of COVID-19. The first part of this paper will analyse the global discussions surrounding the concept of vaccination and the experience and best practice of mandating vaccination programs. The second part of this paper touches on the context of vaccination in Malaysia. The second part would delve into the legal discussion on the extent of the Prevention and Control of Infectious Disease Act mandating vaccination programs. The third part highlights the doctrine of harm principles and insights into the Maqasid Syar'iyyah surrounding vaccination for Muslims. The paper will then elaborate on the methodology as well as the discussion regarding this subject matter. The paper ends with a conclusion.

\section{Global Literature on Vaccination}

\section{What is Vaccination?}

The World Health Organization's (WHO) 1946 Constitution decreed that 'the health of all people is fundamental to attaining peace and security and depends upon the total cooperation of individuals and states. In attaining so, vaccination has been regarded as a global public health success (Glover-Thomas, 2019). Vaccines, used as prophylaxis, prevent infection by training the immune system to prepare it to fight against disease in the event of exposure. Vaccines provide the best protection against diseases such as flu, HPV, Polio, Rotavirus, Rubella, Tetanus and currently, severe acute respiratory syndrome coronavirus two or SARS-CoV-2 (COVID-19), primarily among children, the elderly, and those with compromised and weakened immune system (CDC, 2021). Vaccines defend the vaccinated and simultaneously protect others who are unable to be vaccinated by preventing the disease from spreading. Once a significant percentage of the population has been vaccinated, 'herd immunity is achieved whereby there is little likelihood of the disease to continue to spread uncontrollably within a said population (Young, 2021).

How do vaccines work? Together with the body's natural immune system, vaccines develop further immunity against certain diseases. The creation of vaccines undergoes extensive lab work and testing to ensure they are safe to be taken. After testing, clinical studies are performed on their safety before being licensed and regularly monitored. In emergency cases, such as in response to the COVID-19 
global pandemic, vaccines may receive accelerated approval through licensing bodies such as the US Food and Drug Administration (FDA) but still be subjected to various fitness requirements before being released to the public (Young, 2021). This was the case for most of the COVID-19 vaccines, which was granted Emergency Use Authorization (EUA), subject to further full biologics licenses (Gostin, Salmon and Larson, 2020). On this note, mandating vaccination will ensure comprehensive protection and quicken the achievement of herd immunity. It is an order requiring individuals to be subjected to vaccinations where simple rejections will not suffice and can invoke penalty impositions (Glover-Thomas, 2019).

\section{The History and Reasonings of the Anti-Vaccination Movement}

Young (2021) viewed that the best policies to promulgate vaccination efforts are to increase effective education on vaccines and make it more difficult to be exempted from vaccination. However, the threat of vaccine hesitancy or the Anti-Vaccination Movement (also known as anti-vax) jeopardises humanity's health. Vaccine hesitancy is defined as "a delay in acceptance or refusal of vaccination despite the availability of vaccination services". (Almalki et al., 2021) In 2019, WHO reported vaccine hesitancy as one of the top ten threats to global health, reversing years of progress made resolving vaccine-preventable diseases (WHO, 2019).

History recorded opposition to vaccines from as early as 1772 , when it was thought that vaccines were meant to hinder God's punishment of humankind for its sins Young (, 2021). Young opined that antivaccination groups have always tirelessly worked to dismantle the implementation of effective immunisation programs and policies. The rhetoric is often caused by historical crises involving vaccines, such as the 1955 polio vaccine case, whereby some batches contained life poliovirus, even though it had passed the safety testing. In the New York Times (2021), Jan Hoffman commented that although many parents tend to pay heed to the minimal cases of adverse effects compared to the total number of doses given, causing paranoia and reducing the likelihood of their children being vaccinated. The modern opposition was primarily sparked by a paper written by Andre Wakefield and 12 colleagues in 1998, who suggested a connection between the measles, mumps and rubella vaccine with autism (Young, 2021). However, further studies were immediately conducted that proved to the contrary. The paper was then retracted by 10 of the authors, claiming insufficient data. In 2010, the publication completely retracted the study, and the authors were found guilty of ethics violation, scientific misrepresentation and fraud. Regardless, the paper caused a domino effect that plummeted vaccination ratings across the globe. Gallagher (2019) added that misconceptions and prejudice against the pharmaceutical industry also propagated the hesitancy in vaccination, as some believed that doctors merely promote vaccines due to non-existent ties to the industry, which led to further scepticism in vaccination.

The age of easy access to information exacerbated vaccination hesitancy. Misleading comments and statements by celebrities and social media influencers added oil to the fire as parents are more likely to believe the experiences of an individual rather than hard facts and abstract numbers (Hoffman, 2021). The spread of false information by opponents of vaccination via news forums and social media made the easy public targets. There is an exponentially growing trend of individuals seeking health information from "user generated" websites and mediums, such as online newsgroups or blogs, rather than evidence-based websites (Young, 2021). The spread of vaccine hesitancy, strengthened by inaccurate misinformation, endangers the health and safety of the entire human race. Nevertheless, despite the dangers of vaccine hesitancy, vaccines and vaccination programs significantly lowered the mortality and morbidity rate of infectious diseases (Gravagna et al., 2020).

\section{Global Legal Framework on Vaccination in the Education Sector}

Young (2021) viewed that relevant laws and policies are pivotal in ensuring proper vaccinations in combating outbreaks and the spread of diseases. These legal frameworks enable authorities to address those who refuse to be vaccinated and provide legal sanctions for non-compliance. Gravagna et al. (2020) observed that more than 100 countries around the globe have mandatory national policies 
involving various vaccine-preventable diseases and specify at least one penalty associated with noncompliance, which correlates to vaccination uptakes and lower incidences of diseases.

Gostin, Salmon and Larson (2020) connote that colleges and universities will require a high level of vaccination among students, faculty members, and staff to ensure a safe environment for students to return. There would be a high risk of transmission if students were to sit in a crowded classroom for long durations of time. Similar connotations were made to school children, teachers and staff to enable a safe return to school. Gostin, however, further commented that such mandates must be accompanied by licensing by the FDA with reliable data on the safety and efficacy of school-aged children. The writers warned of the counterproductivity in mandating a vaccine among populations that do not widely support vaccination.

In the United States of America, there are no guidelines issued by the federal government on vaccination requirements for colleges and universities. However, state governments implement their state-wide directives on COVID-19 vaccination rules for public colleges and universities. Private colleges and universities are exempted from these state-wide directives, which also accord religious exemptions. The US Centers for Disease Control and Prevention (CDC) provides for Guidelines for COVID-19 Prevention in K-12 Schools and Guidelines for Institutions of Higher Learning (CDC, 2021). These guidelines do not supplant federal, state, tribal, local or territorial health and safety laws, rules and regulations. This patchwork approach is noted to leave the vast majority of tertiary education institutions subjected to unclear directives, loopholes, and legal complications in enforcing mandatory requirements for students and faculty members to be vaccinated before entering campuses (NBC, 2021).

The United Kingdom (UK) is undergoing massive vaccination drives for its younger citizens. Young people between the age of 12 to 17 years old are undergoing their vaccinations. However, it is not mandatory. Underage children are subject to parental consent. Under the Gillick competence rule, older children in secondary schools may be determined sufficiently mature enough by relevant healthcare professionals to fully understand what is involved in the vaccination and thereby capable of providing their own consent to be vaccinated. It is also not mandatory for students of higher education to be vaccinated as a precursor to returning to campus. The government of the UK promotes encouragement by higher education providers to students to be vaccinated as soon as possible. (GOV.UK, 2021)

The Ministry of Human Resources and Social Development of Saudi Arabia has in May 2021 mandated that all public and private sector workers who wish to attend the workplace must be vaccinated. This includes the education sector as well, such as schools, colleges and universities. Saudi Arabia's official news portal, Saudi Press Agency, reported that as of August 2021, vaccination has also been mandated to enter any government, private or education establishment and the usage of public transport. The Saudi Arabian Ministry of Education confirmed that students over the age of 12 would only be granted access to school premises subject to being fully vaccinated. Students must prove their status via the Tawakkalna mobile app, developed by the Saudi Arabian government to facilitate the issuance of movement permits and contract tracing in the fight against the COVID-19 pandemic.

The European Court of Human Rights passed a judgment no. ECHR 116 (2021) on 8 April 2021 establishes the principle of mandatory vaccination, referencing mandatory vaccination for school children. The court deemed the necessity for mandatory vaccination in some instances to be considered to protect public health and, thus, necessary action in a democratic society. Article 8 of the European Convention on Human Rights (ECHR) protects the right of non-interference in the private life of an individual. However, interference by a public authority can be admitted if provided by the law if such action is a necessary measure, in a democratic society, for national and public security, the economic well-being of the country, defence of order and prevention of crimes, protection of other people health, rights and freedom. (Frati et al., 2021) As deemed by the ECHR, interference such as to impose vaccination to specific categories of the community can be remarked as necessary in a democratic society and justified with the view of fulfilling an urgent social need with proportionate measures taken in line with the legitimate aim. 
DOI: https://doi.org/10.47405/mjssh.v6i10.1081

By way of the Decree-Law No. 111/2021, the Italian Council of Ministers had mandated proving completed COVID-19 vaccination as a requirement for students, teachers, faculty members and staff entrance into school or university grounds, save for underage students. School and university administration will verify the possession of the COVID-19 Green Certification or Green Pass via the mobile app or a printed copy. Failure to comply will result in an inability to access school or university grounds and financial penalties. Teachers, faculty members and staff may also be subjected to further administrative sanctions as they will be deemed absent.

\section{Malaysia and Vaccination}

Following the global increase in the number of persons infected by the COVID-19 virus and the onset of new variants, countries including Malaysia are grappling with curbing the spread through vaccination. At present, the primary vaccination campaign implemented by the Malaysian government is the National COVID-19 Immunisation Programme, commonly known as PICK, administered by The Special Committee for Ensuring Access To COVID-19 Vaccine Supply (JKJAV). The Star (2021) reported on 7 September 2021 that almost $70 \%$ of Malaysia's adult population has been fully vaccinated. Progressively, it was reported by the same portal on 19 September 2021 that there was an increase $(77 \%)$, bringing a total of $21,861,904$ adult individuals, or $88.3 \%$ of the country's adult population, has received at least one dose of the vaccine. As of September 2021, Malaysia has administered more than 40 million vaccine doses, and the cumulative breakdown according to states is shown in Figure 1.

Figure 1: Cumulative Breakdown of Vaccinated States in Malaysia

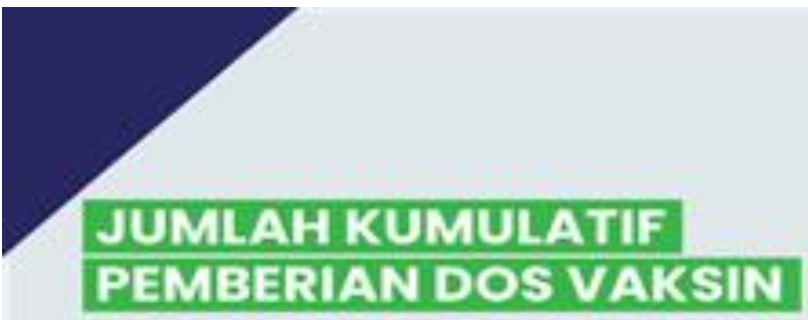

19 SEPTEMBER 2021 11:59 MALAM

\begin{tabular}{|c|c|c|c|c|c|c|}
\hline \multirow{2}{*}{$\begin{array}{l}\text { Mrotal } \\
\text { MALAY3iA }\end{array}$} & \multirow{2}{*}{ 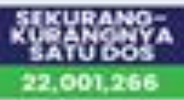 } & \multirow{2}{*}{ ovAksinhs } & \multicolumn{2}{|c|}{ X POPULAST KESELURUAAN } & \multicolumn{2}{|c|}{ X FOFULASI DEWASA } \\
\hline & & & 67.4 & 50.5 & 038 & 70.8 \\
\hline LEMBAH KLANO & $7,074,983$ & $6,566,450$ & 84.0 & 78.0 & n4.8** & $106.5 *$ \\
\hline W.P. LABUAN & 73,865 & 67,039 & 74.2 & 67.3 & $10.4 .2 *$ & 97.8 \\
\hline NEOERI SEMBIL.AN & 823,591 & 763,282 & 73.0 & 67.6 & $101.1 \%$ & 93.7 \\
\hline SARAWAK & $1,949,521$ & $1,822,564$ & 69.2 & 54.7 & 92.1 & 89.2 \\
\hline PEgus & 173,314 & 152,367 & 68.0 & 59.8 & 95.6 & 84.0 \\
\hline TERENGOANU & 731,989 & 627,373 & 58.1 & 49.8 & 90.5 & 77.6 \\
\hline MELAKA & 615,278 & 522,510 & 66.0 & 56.0 & 90.8 & m.1 \\
\hline PULAU PINANO & $1,293,981$ & $1,017,982$ & 73.0 & 57.4 & 94.6 & 74.5 \\
\hline NOHOR & $2,497,612$ & $1,885,599$ & 66.1 & 49.9 & 92.1 & 69.5 \\
\hline КEDАН & $1,278,479$ & 951,148 & 58.5 & 43.5 & 82.9 & 61.7 \\
\hline PERAK & $1,551,872$ & $1,131,970$ & 61.8 & 45.1 & B3.3 & 60.8 \\
\hline PAHANO & 980,553 & 713,544 & 58.4 & 42.5 & 83.4 & 60.7 \\
\hline KELANTAN & 958,500 & 78,584 & 50.3 & 37.7 & 77.4 & 58.1 \\
\hline SABAH & $1,997,728$ & $1,512,920$ & 51.1 & 38.7 & 69.0 & 54.8 \\
\hline \multicolumn{7}{|c|}{ 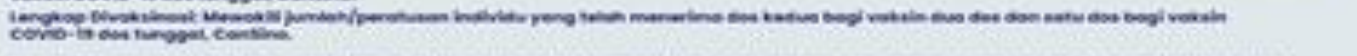 } \\
\hline \multicolumn{7}{|c|}{ 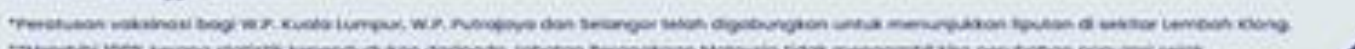 } \\
\hline \multicolumn{7}{|c|}{ 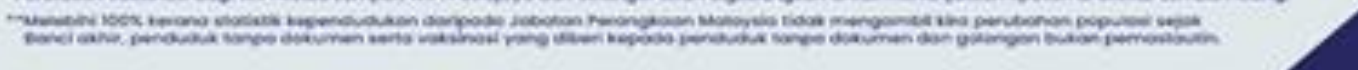 } \\
\hline \multicolumn{7}{|c|}{ vaksincovid.gov.my } \\
\hline
\end{tabular}


The Covid Vax live record, which reflects 40,375,056 vaccines distributed under the National COVID19 Immunisation Programme, clearly shows that the majority of Malaysia's population strongly endorses vaccination. Furthermore, today, Malaysia averaged about 230,712 doses daily while it is set to start its vaccine rollout to teenagers.

Over the past two years, there has been a steady increase in Malaysia's vaccination rates. Nevertheless, for the most part, the smooth sailing programme was still afflicted with several issues ranging from slow vaccine rollout in the beginning and logistical issues with the MySejahtera's application. Ranking above all is also the alarming divergence between those consenting to be vaccinated and anti-vaxxers. These two extremes have created an ongoing dilemma as currently, in Malaysia, vaccination is not mandatory. In February 2021, the then Minister for COVID-19 Immunisation Programme reiterated the government's stance that there is no compulsion to be vaccinated as COVID-19 vaccines should be taken voluntarily, citing legal grounds (Azil. F, 2021).

Research indicated that policies that mandate vaccination has always been controversial (Eve et al., 2013), and various news outlets covered the increasing trend of opposition towards vaccines and the prevalence of anti-vaxxers amongst celebrities, teachers, and students. Evidently, according to Noh (2021), the Johor education committee chairman highlighted 563 teachers in the state of Johor still refuse to be vaccinated. It is not surprising that a minority of students are also starting to refuse vaccines as in August, Bahaudin (2021) reported three students drastically lodged a police report rejecting the vaccine following the government's announcement to start vaccinating school students. The teenagers mentioned that the decision was made after gathering information on vaccines from family and online news, citing holistic and religious ways as the better option to prevent COVID-19.

However, the recent announcement of the education sector's re-opening (Rodzi. N, 2021) begs the question of the direct dangers posed by anti-vaxxers. Following this, and in achieving higher vaccine coverage, the Minister of Health suggested making vaccination compulsory for teachers (The Star, 2021). This was followed by another statement reported by The Star (2021) confirming that the Ministry of Health is discussing with the Public Service Department to impose penalties for civil servants, including teachers who refuse to get vaccinated. In addition, Bernama (2021) highlighted that according to Senior Education Minister Datuk Dr Radzi Jidin Buang, teachers refusing vaccines would be given other tasks instead of physical teaching. Echoing the same sentiment, The Star (2021) reported that calls by NGO's pushing for the offer of an early retirement scheme (VSS) being made available for teachers refusing vaccination. Despite the government's hesitancy to impose mandatory vaccination, this sets a stern tone for civil servants who refuse to get vaccinated, in line with the movement and efforts towards mandatory vaccination.

Nonetheless, the immediate challenge remains as there are no specific laws enacted regarding mandatory vaccination. In ensuring that schools and universities are safe grounds, stricter policies and circulars towards mandatory vaccination in addressing anti-vaxxers must urgently be introduced before re-opening the education sector.

\section{Malaysia's Legal Framework on COVID-19 Vaccination}

One of the ways that the institutional and legal framework has been made favourable to the citizens is by the enactment and enforcement of relevant legislations and policies to ensure that COVID-19 is effectively managed. Predominantly, when discussing COVID-19 in Malaysia, the Federal Constitution must be the first reference as it is the primary law of the land that safeguards and protects the rights of every citizen. This is important in threading the ethical dilemma of mandatory vaccination whilst safeguarding individual rights (CodeBlue, 2021). Every one of the COVID-19 regulations in Malaysia is based on and can be traced back to The Prevention and Control of Infectious Diseases Act 1988 (hereinafter referred to as the Act), which was enacted by incorporating the theme of recovery on prevention and control of infectious diseases. The term Infectious disease here refers to "any disease specified in the First Schedule" of the Act. Even though COVID-19 is not explicitly listed, this new disease falls under the classification of "any other life-threatening microbial infection" in the said schedule. 
Referring to Section 10 of the Act, it enforces a duty on every adult occupant in a house who becomes aware of any infectious diseases to notify the case through notice with the least possible delay. The exact section also makes it obligatory for any medical practitioner who treats or becomes aware of any infectious diseases in any premises to notify the case immediately. Apart from the notification, Section 11(1) of the Act provides that if the Minister of Health is satisfied that there is an outbreak or threat of an epidemic of any infectious disease in any area in Malaysia, the Minister may declare that area as an infectious local area. In addition to that, the section also allows the Minister via regulation to prescribe measures to control or prevent the spread of infectious disease within or from an infected local area. Such measures include directing any person or class or category of persons to subject themselves to treatment or immunisation; isolation, observation, or surveillance; or any other measures considered to be necessary. It is interesting to note that Section 11(5) further imposes a penalty mechanism in the event of any refusal to comply with the direction of authorised officers.

Subsequently, Section 12 of the Act provides that it is an offence for anyone who knows or has reason to believe that he is suffering from infectious disease but at the same time exposes other persons to the risk of infection by his presence or conduct in any public place or any other place used in common by persons other than family members and household (except places where he obtains medical treatment) and any person who contravenes this section commits an offence. In this context, it is also worthwhile to consider Part V of the Act, which explicitly discusses offences and penalties. Section 22 of the Act emphasised that any person who disobeys any lawful order, directions or restrictions imposed by any authorised officer or has breached any rules or regulations made under the Control of Prevention and Control of Infectious Diseases Act 1988 commits an offence under the said act. The penalty and compounding of offences were also discussed under Section 24 and Section 25 of the Act.

The Act echoes the sentiment of societal living and public interest, where duty is imposed on every individual to combat any infectious disease, including the current COVID-19 actively. Notwithstanding the fact that the Act has existed for decades, it has successfully stood the test of time, and several researchers highlighted its importance in combating infectious diseases. For example, Zarina et al. (2013) carried out a qualitative study and found that the enforcement reasoning and effective application of the Act are relevant in combating dengue fever towards urban sustainability.

However, it is important to note that thirty-two years since the passing of the Act in 1988, no immediate review or amendment has taken place. Recently, the Director-General of Health, Tan Sri Dr Noor Hisham Abdullah announced a proposed revision to the Act pertaining to the penalty and compound of offences and one of the suggestions was to increase the fine for compoundable offences from the current RM1,000 to RM10,000 (The New Straits Times 2021). The proposed amendment is a good initiative to ensure effectiveness of the regulations and at the same time, paves greater opportunities to continue with the fight for further amendments involving mandatory vaccination.

\section{Guiding Principles on Vaccination}

\section{Vaccination and The Harm Principle}

The literature discussing the notion of mandatory vaccination often relates to the Harm Principle. The principle was first introduced by English philosopher John Stuart Mill in 1859 or known as Mill's Harm Principle (Mill, 1859). Mill propagate that compulsory vaccination for education sectors can be justified based on the "Harm Principle". According to Willem V.A (2021), the harm principle determines that individuals' human rights can be limited to prevent harm to other individuals or the public at large, which means more people of all ages who get the vaccine, the safer everyone will be. The only purpose for which power can be rightfully exercised over any member of a civilised community, against his will, is to prevent harm to others. Mill (1859) formulated the following principle, which refers to fairness requirements: 
“... everyone who receives the protection of society owes a return for the benefit, and the fact of living in society renders it indispensable that each should be found to observe a particular line of conduct towards the rest. This conduct consists (...) in each person's bearing his share (...) of the labours and sacrifices incurred for defending the society or its members from injury and molestation..."

Suppose non-vaccination harms or risks harming others, then failing to vaccinate as bad as positively doing something harms or risks harming others (Mill, 1859). Jessica Flanigan (2014) has argued that failure to vaccinate should be prohibited, that is, that vaccination should be compulsory based on harm prevention, in the same way as people are prevented from randomly firing a gun in an open space. In this respect, an infectious disease is like a bullet that can be shot and harm or even kill innocent people. This is also supported by Giubilini et al. (2018), which agreed that the non-vaccinated individual would be causally and morally responsible for the harm caused to the other if the non-vaccinated individual infected another individual. A. Giubilini (2019) again emphasised and concluded that it is an ethical approach for the state to enforce and requires each individual to be vaccinated or to vaccinate their children, in the absence of legitimate medical reasons for exemptions; in other words, enforcing compulsory vaccination without non-medical exemptions is an ethical obligation of states because compulsory vaccination meets the requirements posed by the ethical principles that should inform policymaking, namely, maximisation of expected utility, fairness, and least restrictive alternative if adequately understood. It is a collective responsibility to realise herd immunity. The European Court of Human Rights passed a judgment no. ECHR 116 (2021) on 8 April 2021, which established the principle of mandatory vaccination for school children and administrative sanctions imposed by the Italian Council of Ministers on failure to complete COVID-19 vaccination, was actually in line with the Harm Principle discussed above.

\section{Maqasid Syar'iyyah And Islamic Perspective On COVID-19 Vaccination}

As discussed above, the Harm Principle has significant similarities with the Maqasid Syar'iyyah. Among the significant factors that could drive vaccine refusal and hesitancy are personal or religious beliefs, especially among Muslims. In order to help address some of the perceived religious concerns that drive hesitancy to the COVID-19 vaccine, several international senior religious figures and scholars have taken on the responsibility of exploring and highlighting issues around COVID-19 vaccines. The International Islamic Fiqh Academy (IIFA), a global Jeddah-based Islamic institution for the advanced study of Islamic jurisprudence and law, issued a fatwa on COVID-19 vaccines, saying that it permits all indiscriminately vaccines authorised for use. Scholars even said shots could be purchased using some, not all, of the obligatory Zakat money (Maha El Koum, 2021). In Malaysia, some states, such as Penang, agreed to implement Compulsory vaccination by the Mufti of Penang, Dato Seri Dr Wan Salim, effective from 3 June 2021 (Irsyad Al-Fatwa, 2021). Perlis Fatwa Committee has also decided that vaccination is obligatory for Muslims because it is proven that vaccination provides the most effective method in preventing diseases from spreading (Bernama, 2016). The 10th Resolution of the Muzakarah Committee of National Council Fatwa in Islamic Affairs had issued a ruling that COVID-19 Vaccination is "harus" and compulsory to those designated by the Government of Malaysia (Rafidah, 2021). This is being emphasised in the Quran, Surah Al-Baqarah: 195, "And spend of your substance in the cause of Allah, and make not your own hands contribute to (your) destruction, but do good; for Allah loveth those who do good". This decision was supported by the Mufti of the Federal Territories Office at the 2/2021 Federal Territories Islamic Law Consultative Committee Meeting to apply the same ruling (Dr Luqman, 2021). It was related to the authority of Abu Sa'id al-Khudri, (RA), that the Messenger of Allah (saw) said: "It is not allowed to do harm nor to allow being harmed." [Ibn Majah, Al-Daraqutni].

Another factor that anti-vaxxer might have argued was the legality of the ingredients of the vaccines. Islamic scholars and experts have come out with valid and reasonable justification. Vaccines are permissible if the material used is halal and not harmful. Universiti Utara Malaysia senior lecturer in Islamic business studies Dr Mohd Murshidi Mohd Noor said the majority of contemporary Muslim scholars are of the view that vaccines containing any porcine element can be permitted for use provided that the istihalah process has taken place properly and the structure of the original substance has been 
altered completely (Malay Mail, 2021). According to Rosman et al. (2020) and Malay Mail (2021), Istihalah is a natural process that affects the legality from forbidden or haram to halal of an edible substance due to changes in its elements. In other words, a substance obtained from a prohibited source has changed its chemical structure and physical characteristics. It has been turned into another substance with other characteristics and becomes halal and permissible. This is also the view of the Hanafi school and agreed upon by well-known Islamic scholars Sheikh Yusuf Al-Qaradawi and Sheikh Wahbah Al-Zuhaili. Thus, eliminating the properties and characteristics of the original element in the substance. Muzakarah Committee Meeting Perlis mufti Mohd Asri Zainul Abidin also said that "Even if there is an ingredient which is not permissible, the chemical transformation process will make it clean and halal." (Hassan, 2020). Therefore, vaccination is compatible with Islam's idea of preventative medicine and also meets the principles of Maqasid Syar'iyyah when more specifically defined because the effects of vaccination provide advantages and repel damage to people, families, communities, and countries. Therefore, the principle of vaccination complies with Islamic law's objectives, namely "jalbu al-masalih wa daru al-mafasid."

\section{Vaccination Discussion on the Maqasid Syar'iyyah in COVID-19 Vaccination Issues}

Maqasid is the plural of Maqasad and comes from the verbal root of Qasada. Literally, it means to intend, to take a middle course and to walk towards. From this root comes the noun Qasd, which means a goal, an aim, or an aspiration. The second part of the title is the word Syariah, a noun meaning a path to a water hole, and in its more common usage, the law of God as revealed to the Prophet (Abdul Aziz \& Mohamad, 2013). Maqasid Syar'iyyah summarises the overall purpose of Syariah more simply and easily to be understood. Maqasid Syar'iyyah can be applied in various aspects of life and connected to various scientific disciplines to provide solutions to various problems in human life (Al-Awwa, 2006). Vaccination in Islamic perspective is concerned directly with life and health and protection of the family and generation which is relevant with the objectives (maqāșid) of Syariah, namely Hifz al-deen (religion), Hifz al-nafs (life), Hifz al-'aql (intellect), Hifz al-nasl (lineage) and Hifz al-mal (property) and upholds the spirit of al-wiqayah khairun min al-'ilaj (prevention is better than cure) (Abul Fadl, 2014). Discussion on the Maqasid Syar'iyyah aims to safeguard the societal benefit (maslahah) and prevent them from harm (darar) through mandatory COVID-19 vaccination. According to Muhsin (2019), this is achievable by applying the Islamic sub-legal maxim, which is the "greater harm should be prevented by committing the lesser harm" (Al- Ḍarar al- ashadd Yudfa bi al-darar al-Akhaff) and "personal injury should be incurred to prevent general injury" (yutahammal al- darar al-Khass li al- daf al-darar al-amm) which concern on the societal benefit instead of individual benefit. Secular theories also acknowledge the preponderance of public benefit in contrast to the personal benefit, in line with the maxim "no one shall be deprived of his possessions except in the public interest" (Muhsin, 2019). Immunisation does not protect only the individual who had received vaccinations, but it also protects the entire families, community, and country (Nurul \& Zuhaira (2018). Syeikh Abdul Aziz bin Abdullah bin Baz, a Saudi Arabian Islamic scholar, has remarked that vaccination to curb the spread of contagious disease is highly encouraged (Ahmed Sarfraz et al., 2014).

\section{Protection of Religion (AI-Din)}

The first fundamental value under Maqasid Syar'iyyah is the protection of religion (Al-Din). That is the most essential value that Muslims must uphold at all levels. At a personal level, al-din is protected by the practice of several types of 'ibadah,' such as completing five prayers, fasting, paying zakah, and making hajj. The vaccination fulfils all Maqasid Syar'iyyah aims when connecting vaccination with religion preservation (hifz addin) and life preservation (hifz Al-nafs) (Ebrahim, 2014). Concerning the protection of al-din with the vaccination, vaccination entails following one of the Islamic rules prescribed by the Prophet SAW: seeking medical help and finding a treatment for the discomfort. Muslims, in particular, can implement other Islamic principles such as fardhu' ain and fardhu kifayah properly and precisely through indirect health care measures such as vaccination. Despite that, the patient's right to autonomy must consider the health of others. It is not in the best interests of one person to intervene in the best interests of another without that person's consent and willingness. From a hadith by Saud, Rasulullah SAW said, "When you hear of cholera in a place, then do not come to that place. And if it happens somewhere while you are in it, then do not run away from it". The use of 
vaccinations to boost immunity is mandated by Syariah, which also emphasises the significance of vaccination to boost immunity against the emergence of several infectious illnesses, as suggested by doctors and national and global change institutions. Vaccines are also essential since their idea aligns with the Islamic ideal of preventative medicine.

\section{Protection of Life (al-Nafs)}

The second fundamental that needs to be considered is the protection of life or can also be called as protection of al-Nafs. Since life is so important and valuable to everyone, therefore, it must be protected in all circumstances regardless of one's life status and religion (Abul Fadl, 2014). It is an obligation for every person to protect their own life and other people's lives. This is emphasised in the Quran, Surah al-Maidah verse 32, “...And whoso saves a (human) life it is as if he has saved the entire mankind..." Applying this to vaccination means that the vaccine must still be provided to persons since the risk of damage is more significant if the vaccine is not provided. The mortality rate due to COVID19 is worrying. According to data from the Ministry of Health (MoH), as of 18 September 2021, the country's total fatalities linked to the COVID-19 amounted to 23,067 (Izzul Ikram, 2021). Vaccines can reduce morbidity and mortality in the country by preventing vaccine-preventable illnesses that can harm human health and life. Personal injury would be far less significant than harm in the form of a disease that would put the entire population at risk. If people do not get vaccinated, the sickness will remain in their bodies.

Furthermore, the amount of each additive in vaccinations is relatively tiny. Humans are constantly exposed to far greater doses of these substances. These chemicals are used in vaccinations to make them safer and more effective. Each vaccination is thoroughly evaluated to ensure that it is both safe and effective. Antigens are contained in all vaccinations. Vaccines function because of antigens. They cause the body to produce the immunological response required to fight illness. Antigens occur in a variety of shapes and sizes. A vaccine's form is chosen because studies show it is the most effective strategy to protect against certain viruses.

\section{Methodology}

This paper aimed to weigh the legal argument on the possibility of imposing mandatory COVID-19 vaccination in Malaysia's education sector to eradicate this deadly virus permanently. This paper adopts a qualitative research methodology, in which the secondary data analysis is conducted using a doctrinal legal approach. Such data is obtained from the primary sources: vaccination-related legislation from various jurisdictions and various secondary sources, including textbooks, journal articles, government reports, newspaper articles, and online sources. The data collected was then analysed by using legal content analysis and critical analysis methodologies.

\section{Discussion}

As suggested by various works of literature, the current trend among many jurisdictions is towards mandating compulsory vaccination to their citizens. Countries such as Saudi Arabia and Italy have actively developed policies, guidelines, and laws to ensure every living individual within their jurisdiction is vaccinated. The driver of the notion of imposing mandatory vaccination among these countries, be it Saudi Arabia or Italy, is either the Harm Principles proposed by Mills or the Maqasid Syar'iyyah as recommended by the Quran and Sunnah. Both legal and Islamic principles mentioned earlier put forward the notion of societal interest for safety and health over individual and personal liberties and choice. Given ensuring the majority of the public are protected, the vaccination was seen as a lesser evil over the rights to choose enjoyed by one person.

The Acts have been the point of reference in Malaysia, where the Malaysian government can impose mandatory vaccinations for each individual. The existing section of the Act hinted that any individual who did not follow the instructions to the immunisations program or refuse to comply with the said 
program could be found liable for an offence under this Act. Unfortunately, the government is hesitant to impose such a sanction for those who refuse to comply. Instead, they took a diplomatic approach of persuading the people to be vaccinated. Soft approaches such as vaccination campaigns to educate and awareness programs were conducted. Apart from campaigning, the government has adopted another soft approach on mandatory vaccination, where those who have not been vaccinated might not enjoy the benefits enjoyed by vaccinated individuals. A fatwa was gazetted on mandatory vaccination in the state of Penang reflected the importance of getting vaccinated subtly.

The majority of Malaysian society is inclined towards vaccination. This statement can be supported by the percentage of vaccinated individuals increasing daily. As the population is moving towards accepting vaccination as a means to exit the current pandemic, several movements consist of a group of NGOs proposing to the current government to implement mandatory vaccination by amending the existing law. The majority of the Malaysians has urged such complex approaches as a response to the uprising of the anti-vaccine group, particularly within the education sector. As a recommendation, this paper would like to echo the recommendations put forward by the Health DG, Dr Hisham, which suggested that the law should be amended in enforcing stricter punishment for those who refuse to comply with the vaccination program without any grounded justifications.

\section{Conclusion}

It is a truism that vaccination was not meant to eradicate and combat the ever-evolving COVID-19 virus. Ever since it emerged, the virus has had no cure as science is concerned, and the treatment was meant to address the symptom perse. However, vaccination has been scientifically proven to be the best alternative to ensure that the spread of COVID-19 is contained. The pandemic has impacted the education sector, resulting in a significant restructuring of how education was conducted and delivered. In the recent development, the Ministry of Education has decided to re-open schools and universities, the concern over individuals within the education sector who refuse to be vaccinated has arisen. Hence, the notion of mandatory vaccination, which is in line with the Harm Principles and the Maqasid Syar'iyyah, seems feasible among those who refuse to be vaccinated within the education sector to prevent more significant harm and to ensure the education process can be delivered in a safety bubble. Apart from the existing discussion, future research could be conducted in analysing the lack of application on the existing Section 11 of the Prevention and Control of Infectious Diseases Act and the impediment faced by the current government to rely on such law to impose mandatory vaccination in Malaysia.

\section{References}

Abdul Aziz, Ahmad Faizal \& Mohamad, Shaifulfazlee. (2013): Fulfillment of Maqasid al-Shariah via Takaful. Munich Personal RePEc Archive. https://mpra.ub.uni-muenchen.de/47776/

Abdullah, S. (2021, January 21). Health DG: Draft amendments to Act 342 now with AttorneyGeneral's Chambers. The Straits https://www.nst.com.my/news/nation/2021/01/661946/health-dg-draft-amendments-act-342now-attorney-generals-chambers

Abdullah, S. M. (2021, January 31). Health DG: Draft amendments to Act 342 now with AttorneyGeneral's Chambers. New Straits Times. https://www.nst.com.my/news/nation/2021/01/661946/health-dg-draft-amendments-act-342now-attorney-generals-chambers

Abul Fadl Mohsin Ebrahim. (2014). Vaccination in the Context of Al-Maqasid Al-Shari'Ah (Objectives of Divine Law) and Islamic Medical Jurisprudence'. Arabian Journal of Business and Management Review (Oman Chapter), 3. https://www.arabianjbmr.com/pdfs/OM_ VOL_3_(10)/3.pdf

Adofo, S. (2013). Challenges And Coping Strategies Of Student Nursing Mothers In Tertiary Institutions In The Greater Accra Region Of Ghana (M.Phil). University of Ghana. 
Ahmed, Sarfraz; Othman, Nor Hayati; Sulaiman, Siti Amrah; Mahadeva, Rao U S; Nordin, S; et al. (2014). Resistance to Polio Vaccination in Some Muslim Communities and the Actual Islamic Perspectives - A Critical Review. Research Journal of Pharmacy and Technology; Raipur, $\underline{7(4)}$,

https://www.proquest.com/openview/678070e14241ae51021b50f50ca7572b/1?pqorigsite $=$ gscholar $\& \mathrm{cbl}=1096441$

Almalki, M. J., Alotaibi, A. A., Alabdali, S. H., Zaalah, A. A., Maghfuri, M. W., Qirati, N. H., \& Almalki, S. M. (2021). Acceptability of the COVID-19 Vaccine and Its Determinants among University Students in Saudi Arabia: A Cross-Sectional Study. Vaccines, 9(9), 943. https://doi.org/10.3390/vaccines9090943

Azil, F. (2021, January 23) Vaksin COVID-19: Tiada paksaan, aktivis dan NGO jangan takutkan masyarakat - Khairy. Astro Awani. https://www.astroawani.com/berita-malaysia/vaksincovid19-tiada-paksaan-aktivis-dan-ngo-jangan-takutkan-masyarakat-khairy-284305

Bahaudin, N. H. (2021, August 30). Three students lodge police reports rejecting Covid-19 vaccine. New Straits Times. https://www.nst.com.my/news/nation/2021/08/722824/three-students-lodgepolice-reports-rejecting-covid-19-vaccine

Bernama. (2021, September 4). Teachers Refusing Vaccine Will Be Given Other Assignments. New Strait Times. https://www.nst.com.my/news/nation/2021/09/724302/teachers-refusing-vaccinewill-be-given-other-assignments

Bhatia, G., Dutta, P. K., \& McClure, J. (2020, September 14). Malaysia: the latest coronavirus counts, charts and maps. Reuters. https://graphics.reuters.com/world-coronavirus-tracker-andmaps/countries-and territories/malaysia/

Buang, S. (2021, September 19). Page saran KPM tawar VSS kepada guru tolak vaksin. Malaysiakini; https://www.malaysiakini.com/news/591921

Decreto Legge 6 Augusto 2021, n.111

Dyer, O. (2021). Covid-19: Turkmenistan becomes first country to make vaccination mandatory for all adults. BMJ (Clinical Research ed.), 374, n1766-n1766.

Ebrahim, A. F. M. (2014). Vaccination in the Context of Al-Maqasid Al-Shari ah: Objectives of Divine Law and Islamic Medical Jurisprudence. Oman Chapter of Arabian Journal of Business and Management Review, 3(10), 44-52. https://doi.org/10.12816/0016499

Eve Dubé, Caroline Laberge, Maryse Guay, Paul Bramadat, Réal Roy \& Julie A. Bettinger (2013) Vaccine hesitancy, Human Vaccines \& Immunotherapeutics, 9(8), 1763-1773, DOI: 10.4161/hv.24657

Flanigan J. (2014). A Defense of Compulsory Vaccination. HEC Forum: An Interdisciplinary Journal On Hospitals' Ethical And Legal Issues, 26(1), 5-25. https://doi.org/10.1007/s10730-013-92215

Frati, P., La Russa, R., Di Fazio, N., Del Fante, Z., Delogu, G., \& Fineschi, V. (2021). Compulsory Vaccination for Healthcare Workers in Italy for the Prevention of SARS-CoV-2 Infection. Vaccines, 9(9), 966. https://www.mdpi.com/2076-393X/9/9/966

Giannouchos, T. V., Steletou, E., Saridi, M., \& Souliotis, K. (2021). Should vaccination be mandated? Individuals' perceptions on mandatory vaccination in Greece. Journal of Evaluation in Clinical Practice.

Giubilini, A. (2019). The Ethics of Vaccination, Palgrave Studies in Ethics and Public Policy. Palgrave Pivot. DOI 10.1007/978-3-030-02068-2

Giubilini, A., Douglas, T. \& Savulescu, J. (2018). The Moral Obligation to Be Vaccinated: Utilitarianism, Contractualism, and Collective Easy Rescue. Medicine, Health Care, and Philosophy. https://doi.org/10.1007/s11019- 018-9829-y

Glover-Thomas, N. (2019). The Vaccination Debate in the UK: Compulsory Mandate Versus Voluntary Action in the War Against Infection. Journal of Medical Law and Ethics, 7(1), 47-71. https://www.research.manchester.ac.uk/portal/en/publications/the-vaccination-debate-in-the-ukcompulsory-mandate-versus-voluntary-action-in-the-war-against-infection(4b3aa0d5-c50b4d80-bca7-681601e7b825).html

Gostin, L. O., Salmon, D. A., \& Larson, H. J. (2021). Mandating COVID-19 vaccines. Jama, 325(6), 532-533. https://jamanetwork.com/journals/jama/fullarticle/2774712

Gravagna, K., Becker, A., Valeris-Chacin, R., Mohammed, I., Tambe, S., Awan, F. A., \& Basta, N. E. (2020). Global assessment of national mandatory vaccination policies and consequences of non- 
DOI: https://doi.org/10.47405/mjssh.v6i10.1081

compliance. $\quad$ Vaccine, 38(49),

https://www.sciencedirect.com/science/article/pii/S0264410X20312342

7865-7873.

Gravagna, K., Becker, A., Valeris-Chacin, R., Mohammed, I., Tambe, S., Awan, F. A., ... \& Basta, N. E. (2020). Global assessment of national mandatory vaccination policies and consequences of non-compliance. Vaccine, 38(49), 7865-7873.

Hassan, H. (2020, December 10). Malaysia Says Halal Issue Won’t Affect Covid-19 Vaccine Roll-Out Amid Concerns Among Muslims. The Straits Times. https://www.straitstimes.com/asia/seasia/halal-issue-will-not-impede-malaysias-vaccine-roll-out-says-health-chief-amid-muslim

Historical Safety Concerns | Vaccine Safety | CDC. (2021, September 4). Centers for Disease Control and Prevention. https://www.cdc.gov/vaccinesafety/concerns/concerns-history.html

Hoffman, J. (2021, March 26). How Anti-Vaccine Sentiment Took Hold in the United States. The New York Times. https://www.nytimes.com/2019/09/23/health/anti-vaccination-movement-us.html

Irsyad Al-Fatwa. (2021, June 3). Hukum Suntikan Vaksin Covid-19. Jabatan Mufti Negeri Pulau Pinang.https://mufti.penang.gov.my/index.php/2014-11-12-02-48-39/fatwa/513-irsyad-fatwasuntikan-vaksin-Covid-19/file

JKVAV. (n.d.). Progress Statistics for The National Covid 19 Immunisation Programme. Jawatankuasa Khas Jaminan Akses Bekalan Vaksin COVID-19. https://www.vaksincovid.gov.my/en/statistics/

Kesslen, B., Watkins, M., \& Syed, K. (2021, August 25). Confusing rules, loopholes and legal issues: College vaccination plans are a mess. NBC News. https://www.nbcnews.com/news/usnews/confusing-rules-loopholes-legal-issues-college-vaccination-plans-are-mess-n1267981

Khairy to discuss with Education Ministry on making vaccination compulsory for teachers. (2021, September 3). The Star Online. https://www.thestar.com.my/news/nation/2021/09/03/khairy-todiscuss-with-education-ministry-on-making-vaccination-compulsory-for-teachers

Maha El Koum. (2021, March 13). Vaccine Hesitancy: Why 'anti-vaxxers' refuse to get vaccinated against Covid-19. Doha News. https://www.dohanews.co/covid-19-vaccine-hesitancy-why-antivaxxers-refuse-to-get-vaccinated/

Malay Mail. (2021, January 25). Understanding the Islamic perspective on Covid-19 vaccines. Malay Mail.https://www.malaymail.com/news/malaysia/2021/01/25/understanding-the-islamicperspective-on-covid-19-vaccines/1943703

Mill, J. S. (1859). On Liberty. London: Walter Scott Publishing. In The Project Gutenberg Ebook of On Liberty. https://www.gutenberg.org/files/34901/34901-h/34901-h.htm

Ministers of Media and Education Hold Joint Periodic Press Conference. (2021, August 19). Saudi Press Agency. https://www.spa.gov.sa/viewstory.php?lang=en\&newsid=2275537

Muhammad Salim al-Awwa (2006). Daur al-Maqasid fi al-Tasyri'at al-Mu'asirah. (Kairo: alMaqasid Research Center, 2006)

Muhsin, S. M. (2019). Framework for Harm Elimination in Light of the Islamic Legal Maxims. Islamic Quarterly, 63(2), 233-272.

Noh, M. F. (2021, September 20). 563 Teachers in Johor Still Refuse Vaccination. New Straits Times. https://www.nst.com.my/news/nation/2021/09/728948/563-teachers-johor-still-refusevaccination

Nurul Jannah Mustafa Khan \& Zuhaira Nadiah Zulkipli. (2018). Compulsory Vaccination For Children In Malaysia: Legislation And Realisation. Yuridika Fakultas Hukum Universitas Airlangga. 33(3). DOI: 10.20473/ydk.v33i3.9826

Our World Data. (n.d). Malaysia: Coronavirus Pandemic Country Profile - Our World in Data. https://ourworldindata.org/coronavirus/country/malaysia

Prevention and Control of Infectious Diseases Act 1988

Radhi, N. A. M. (2021, August 4). Malaysia tops in Vaccination rate: New Straits Times. NST Online. Retrieved September 20, 2021, from https://www.nst.com.my/news/nation/2021/08/714696/malaysia-tops-vaccination-rate.

Rafidah Mat Ruzki. (2021, February 14). Hukum vaksin COVID-19 Harus - Mufti Wilayah. Berita Harian Online. https://www.bharian.com.my/berita/nasional/2021/02/785997/hukum-vaksincovid-19-harus-mufti-wilayah

Rodzi, N. (2021, September 12). Schools in several Malaysian states to reopen on Oct 3 at $50 \%$ capacity, SE Asia News \& Top Stories. The Straits Times. https://www.straitstimes.com/asia/seasia/schools-in-several-malaysian-states-to-reopen-on-oct-3-at-50-per-cent-capacity 
Rosman, A. S., Khan, A., Fadzillah, N. A., Darawi, A. B. S., Hehsan, A., Hassan, A. M., Ghazali, M. A. ikhsan, \& Haron, Z. (2020). Fatwa Debate On Porcine Derivatives In Vaccine From The Concept Of Physical And Chemical Transformation (Istihalah) in Islamic Jurisprudence And Science. Journal of Critical Reviews, 7(7), 1037-1045. https://doi.org/10.31838/jcr.07.07.189

Sahibus Samahah Datuk Dr. Luqman. (2021, February 14). Kenyataan Rasmi PMWP Bil. 4/2021 Hukum Pengambilan Vaksin Covid-19. https://muftiwp.gov.my/media-menu/kenyataan-mediapmwp/4670-kenyataan-rasmi-pmwp-bil-4-2021-hukum-pengambilan-vaksin-covid-19

Saudi Arabia: Covid-19 Vaccination Is Mandatory for Entering All Places from Today, Aug 1. (2021, August 2). Saudi Press Agency. https://www.spa.gov.sa/viewfullstory.php?lang=en\&newsid=2267363

Sharifah Zarina Syed Zakaria, Nor Alina Mohamad Roslan, Mazlin Mokhtar, Abdul Samad Hadi, Muhammad Rizal Razman, Jamaluddin Md. Jahi, Zuliskandar Ramli \& Norul Hajar Nordin. (2013). Environmental Management in Dealing with Dengue Fever Cases Towards Urban Sustainability: Study on the Prevention and Control of Infectious Diseases Act 1998 (Act 342). The Social Sciences, 8: 295-299

Susan Gallagher. (Apr. 21, 2019). The Many Faces of Vaccine Hesitancy. Duke Global Health Inst. https://globalhealth.duke.edu/media/news/many-faces-vaccinehesitancy.

Tharmaseelan, M (2021, September 13). Ethical Dilemma of Mandatory Vaccination. Facebook. https://www.facebook.com/codebluenews/.https://codeblue.galencentre.org/2021/09/13/ethicaldilemma-of-mandatory-vaccination-dr-myelone-tharmaseelan/

The Star. (2021, September 19). Khairy: MOH, JPA to discuss penalties for civil servants who refuse Covid-19 vaccination. The Star Online. https://www.thestar.com.my/news/nation/2021/09/19/khairy-moh-jpa-to-discuss-penalties-forcivil-servants-who-refuse-covid-19-vaccination

The Star. (2021, September 21). 77\% of Adult Population Fully Jabbed. The Star Online. https://www.thestar.com.my/news/nation/2021/09/19/77-of-adult-population-fully-jabbed

The Star. (2021, September 3). Khairy to Discuss With Education Ministry On Making Vaccination $\begin{array}{lllll}\text { Compulsory For The Therse } & \end{array}$ https://www.thestar.com.my/news/nation/2021/09/03/khairy-to-discuss-with-educationministry-on-making-vaccination-compulsory-for-teachers

The Star. (n.d.). Dr Noor Hisham: Health Ministry hopes Act 342 can be amended soon. TheStarTV.Com. https://www.thestartv.com/v/dr-noor-hisham-health-ministry-hopes-act-342can-be-amended-soon

Umar Mukhtar Mohd Noor. (2021, February 18). Bayan Linnas Siri Ke-167: Kewajiban Mengambil Vaksin Mengikut Jadual Imunisasi Kebangsaan Daripada Perspektif Islam. Pejabat Mufti Wilayah Persekutuan. https://muftiwp.gov.my/en/artikel/bayan-linnas/3129-bayan-linnas-sirike-166-kewajiban-mengambil-vaksin-mengikut-jadual-imunisasi-kebangsaan-daripadaperspektif-islam

Vavřička and Others v. the Czech Republic (Applications No. 47621/13 and Five Other Applications) the European Court of Human Rights

Verger, P., Dualé, C., Scronias, D., Lenzi, N., Pulcini, C., \& Launay, O. (2021). Attitudes of hospital physicians toward childhood mandatory vaccines in France: A cross-sectional survey. Human Vaccines \& Immunotherapeutics, 1-8.

Willem Van Aardt. (2021). The Mandatory COVID-19 Vaccination of School Children: A Bioethical and Human Rights Assessment. Journal of Vaccines \& Vaccination, 12(3) No: 1000457.

World Health Organization. (1995). Constitution of the world health organization.

World Health Organization. (n.d.). Ten health issues who will tackle this year. World Health Organization. Retrieved September 19, 2021, from https://www.who.int/newsroom/spotlight/ten-threats-to-global-health-in-2019.

Worldwide. (n.d.). Covidvax.Live - Worldwide. https://covidvax.live/location/mys

Yee, X. (2021, September 20). Over 560 teachers in Johor against getting vaccinated, most citing health reasons. The Star Online. https://www.thestar.com.my/news/nation/2021/09/20/over-560teachers-in-johor-against-getting-vaccinated-most-citing-health-reasons

Ying, T. P. (2020, September 1). Review of Act 342 timely, says Dr Noor Hisham. New Straits Times. https://www.nst.com.my/news/nation/2020/09/621209/review-act-342-timely-says-dr-noorhisham 
DOI: https://doi.org/10.47405/mjssh.v6i10.1081

Young, S. (2021). Addressing vaccination hesitancy. University of Miami International and Comparative Law Review, 28(2), 375-404. https://www.ncbi.nlm.nih.gov/pmc/articles/PMC6515949/ 